\title{
Getting young adults back to church: A marketing approach
}

\begin{tabular}{|c|c|}
\hline \multicolumn{2}{|c|}{$\begin{array}{l}\text { Authors: } \\
\text { Michelle C. van der Merwe } \\
\text { Anské F. Grobler }^{2} \\
\text { Arien Strasheim } \\
\text { Lizré Orton }\end{array}$} \\
\hline \multicolumn{2}{|c|}{$\begin{array}{l}\text { Affiliations: } \\
{ }^{1} \text { Department of Marketing } \\
\text { Management, University of } \\
\text { Pretoria, South Africa }\end{array}$} \\
\hline \multicolumn{2}{|c|}{$\begin{array}{l}{ }^{2} \text { Department of Business } \\
\text { Management, University of } \\
\text { Pretoria, South Africa }\end{array}$} \\
\hline \multicolumn{2}{|c|}{$\begin{array}{l}{ }^{3} \text { Department of Human } \\
\text { Resource Management, } \\
\text { University of Pretoria, } \\
\text { South Africa }\end{array}$} \\
\hline \multicolumn{2}{|c|}{$\begin{array}{l}\text { Note: } \\
\text { This article is published in the } \\
\text { section Practical Theology } \\
\text { of the Society for Practical } \\
\text { Theology in South Africa. }\end{array}$} \\
\hline \multicolumn{2}{|c|}{$\begin{array}{l}\text { Correspondence to: } \\
\text { Michelle van der Merwe }\end{array}$} \\
\hline \multicolumn{2}{|c|}{$\begin{array}{l}\text { Email: } \\
\text { michelle.vandermerwe@ } \\
\text { up.ac.za }\end{array}$} \\
\hline \multicolumn{2}{|c|}{$\begin{array}{l}\text { Postal address: } \\
\text { Private Bag X20, Hatfield } \\
0028 \text {, South Africa }\end{array}$} \\
\hline \multicolumn{2}{|c|}{$\begin{array}{l}\text { Received: } 31 \text { Aug. } 2012 \\
\text { Accepted: } 26 \text { Nov. } 2012 \\
\text { Published: } 04 \text { Apr. } 2013\end{array}$} \\
\hline \multicolumn{2}{|c|}{$\begin{array}{l}\text { How to cite this article: } \\
\text { Van der Merwe, M.C., } \\
\text { Grobler, A.F., Strasheim, A. } \\
\text { \& Orton, L., 2013, 'Getting } \\
\text { young adults back to church: } \\
\text { A marketing approach', } \\
\text { HTS Teologiese Studies/ } \\
\text { Theological Studies 69(2), } \\
\text { Art. \#1326, } 12 \text { pages. http:// } \\
\text { dx.doi.org/10.4102/hts. } \\
\text { v69i2.1326 }\end{array}$} \\
\hline \multicolumn{2}{|c|}{$\begin{array}{l}\text { Copyright: } \\
\text { (C) 2013. The Authors. } \\
\text { Licensee: AOSIS } \\
\text { OpenJournals. This work } \\
\text { is licensed under the } \\
\text { Creative Commons } \\
\text { Attribution License. }\end{array}$} \\
\hline \multicolumn{2}{|l|}{ Read online: } \\
\hline 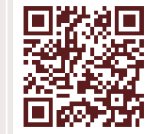 & $\begin{array}{l}\text { Scan this QR } \\
\text { code with your } \\
\text { smart phone or } \\
\text { mobile device } \\
\text { to read online. }\end{array}$ \\
\hline
\end{tabular}

Worldwide, church membership is decreasing. A decline in the number of young adults that attend church services is also evident. The purpose of the research was to determine whether the application of a well-established body of knowledge of marketing theories and principles could be used by churches to encourage young adults to return to the church. The application of services marketing to the church as a non-profit organisation is discussed by focussing on non-physical and physical atmospheric cues in the church's servicescape that could enhance church attendance. A quantitative approach was used by testing the opinions of 200 church service attendees of different denominations. The findings indicated that certain elements in the servicescape of a church may be useful in attracting young adults. It was found that music is a strong determinant of whether young adults attend church services, followed by layout and design of the church and then by the signs and symbols used in the church. Females reported significantly higher levels of positive perceptions concerning the layout and design. Although the research showed that some marketing elements, such as a positive servicescape, could improve church attendance, other personal elements such as forming personal relationships with fellow Christians and God need to be further explored.

\section{Introduction}

Church membership and attendance is decreasing worldwide: 'The currently [sic] crisis of the church in the Western world is that people are becoming less involved with the church as [an] institution' (Dreyer 2004:920). A worldwide decline in the number of young adults that attend services is also evident. Younger members of society have enormous work pressure and, with it, abundant choice for leisure, relaxation and social activities, which could be distracting them from attending church. Another possible reason for decreased church attendance by young adults is their postmodernist view, implying that they are more informed about products and services, among other things, because of the greater accessibility of information (Dreyer 2004:922; Proctor \& Kitchen 2002:145). Young adults can decide whether or not they want to attend services, how often to do so and even what type of church service they would prefer to attend.

Research regarding church attendance patterns emerged in social sciences as far back as the 1960s. These patterns indicated that high involvement with the church is common during childhood. During adolescence there is less involvement. Often, adolescents and young adults leave the church altogether, but a small number do return in their late twenties and early thirties (Dreyer 2004:921-922). The fact that only a small number of young adults return to the church is of great concern as they are the life-blood of the church - without them, the church cannot grow. As Dreyer (2004:936) has suggested, the continual growth of the church is imperative if religious communities are to continue into the future.

In a business context, marketing is used to recruit new customers. Similarly, the question that begs answering is whether the well-established body of knowledge of marketing theories and principles could not be used by churches to attract and retain young adults. Church marketing is not a new concept (Britz \& Müller 2003; North 2004; Santos \& Mathews 2001:179). In fact, Sherman and Devlin (2000:47) state that the use of marketing activities by churches is on the increase. Services marketing is aimed at marketing intangible product offerings, such as health care or travel as opposed to tangible product offerings, such as motor vehicles or clothing. The physical environment in which a service as an intangible product is provided is known as the servicescape. Research has indicated that the servicescape can affect the consumer's service experience either positively or negatively (Bitner 1992:57). Whilst the services offered to customers are intangible, the servicescape provides atmospheric cues such as signs, symbols, layout and design as well as non-physical atmospheric cues such as music (Bitner 1992:62). Servicescape research has examined restaurants, hotels, psychiatric offices and airports, to mention a few (Countryman \& Jang 2006; Wilson 2003), but no research could be found on the application of these marketing principles to a church sermon as an intangible service. 
The purpose of the research was to determine whether physical and non-physical atmospheric cues in the servicescape of a church could be used to encourage young adults to return to the church. It is argued that, if marketing research has indicated that the servicescape can affect consumer's service experience positively or negatively (Bitner 1992:57) and that physical and non-physical cues in the servicescape can enhance the service experience and attract and retain an intended market segment (Eroglu, Machleit \& Davis 2001:178), a positive experience of the servicescape in the church should improve young adults' church attendance. A quantitative approach was used by testing the opinions of 200 young church attendees of different denominations. By applying services marketing principles to the church as a non-profit organisation, a novel perspective is offered on how young adults could be encouraged to return to the church.

The next section briefly explains how a service is viewed as a form of services marketing to market a church as a nonprofit organisation. Particular attention is paid to music, signs and symbols and the layout and the design inside the church as physical and non-physical atmospheric cues in the servicescape of a church, as elements that could positively or negatively influence church attendees' experience of a service. A discussion of the research methodology and the questionnaire used precedes an in-depth presentation of the research results. As the research presents an alternative possible solution to solving the decline in church attendance by young adults, the limitations and recommendations are pointed out before final conclusions are drawn.

\section{Church marketing as services marketing of a non-profit organisation}

The marketing of a service is more challenging than the marketing of a product because selling a product that consumers can see, feel and touch is easier than selling an intangible service, such as banking services. A service can be described as a deed, process or performance that requires some sort of interaction between the consumer and the service provider (Lamb et al. 2010:467). Services are characterised by intangibility, inseparability, heterogeneity and perishability. Intangibility implies that a service cannot be touched; inseparability indicates that a service is consumed at the same time as it is produced; heterogeneity means that a service may differ from one incident to the next; and perishability indicates that a service cannot be stored or saved for future use (Lamb et al. 2010:468-470).

Unlike typical profit-seeking businesses, non-profit organisations exist for reasons other than making a profit and usually (unknowingly) engage in marketing (Lamb et al. 2010:478). Whether profit-seeking or not, organisations provide a product or service that is desired by customers and satisfies a need (Lamb et al. 2010:5). Churches can therefore be described as non-profit organisations that offer a service to a congregation (Santos \& Mathews 2001:279). For the purpose of this research, only the actual service that is traditionally given on a Sunday was investigated.

Since a service (such as a church service) is intangible, inseparable, heterogeneous and perishable, the environment in which the service takes place (that is, the servicescape) gives non-verbal cues regarding the image, purpose, nature and quality of the service (Bitner 1992:62; Lamb et al. 2010:469; Rosenbaum \& Massiah 2011:471). The term 'atmospherics' refers to physical and non-physical cues in the servicescape that can create a specific atmosphere to enhance the service experience for the intended market to positively affect their behaviour and thereby attract and retain them (Eroglu et al. 2001:178). Examples of atmospherics would include lighting, temperature and music (Zeithaml, Bitner \& Gremler 2006:322). Therefore it could be argued that, if a church would like to attract and retain young adults, the atmospherics of the church should be structured to attract young adults and satisfy their needs. In doing so, the church could retain them. The next section focuses on music as a nonphysical cue which could possibly influence atmospherics in the church.

\section{Music as a non-physical atmospheric cue}

Music is a means of triggering moods and communicating non-verbally (Bruner 1990:94). Although the precise nature of the link between music and a servicescape is unknown (Herrington 1996:28), music can be used as a basis to influence a servicescape either positively or negatively (Dubé \& Morin 2001:111; Morin, Dube \& Chebat 2007:118). Music also influences perception in that the nature of the service being offered is perceived to be communicated by the type of music played in the servicescape (Wilson 2003:94). Furthermore, research suggests that the music should match the servicescape and the consumer, since consumers tend to spend more time in an environment when the music that is played matches their preferences (Herrington 1996:28; Wilson 2003:94). The compatibility of the music with the audience's preferences also significantly increases the credibility of commercial messages. Similarly, music in a church can be used as a basis for young adults to experience the church service and arguably also influence the credibility of the message delivered in the service. More importantly, the type of music played in a religious service is most likely to influence the preferred attendance of the services of a specific church denomination.

With regard to the tempo and volume of the music, it has been found that slower music tempos and lower volume in a traditional retail servicescape encourage consumers to take their time whilst shopping. In contrast, faster music tempos and higher volumes have been found to decrease shopping time and tend to make the physical environment more complex, thus increasing the amount of information that needs to be processed at any given time (Herrington 1996:27). 
Man (1998:1) found that, in South Africa, different generations have different attitudes towards and preferences regarding church music and that there is an attempt to deal with the differences in musical style and preferences by offering separate worship services. A great variety of approaches to 'praise and worship' in churches exist. According to Howitt (1998:86), various church denominations have different approaches to church music and prefer different types of music to be played during different services. For example, the perceptions of the tempo, sound and variations of the music may differ according to the preferences of the congregation.

The type of praise and worship reflects the nature of the congregation. Many churches have a contemporary service in addition to a traditional service. The different services offer very different servicescapes due to the difference in the musical styles of the praise and worship. Services with different musical approaches give the congregation the opportunity to choose between different services instead of moving to a different church. It is generally accepted that there is no right or wrong way to praise and worship God, but young adults have different attitudes, expectations, needs and preferences towards praise and worship music. Thus, it is advisable to have a separate service for young adults. Tailoring services to different groups is a form of marketing, called multi-segment targeting (Lamb et al. 2010:177). Therefore, this research explored whether music in the church is perceived to (1) create an atmosphere (Morin et al. 2007:118) that stirs religious feelings; (2) match the tastes and preferences (Wilson 2003:94) of young adults; (3) make use of musical instruments that are enjoyed by young adults; (4) be played at a tempo and volume that satisfies young attendees (Herrington 1996:28); and (5) matches the nature of the service (Herrington 1996:27) in the specific church denomination.

Music, including the music played in the church, is a multidimensional construct (taking into account the church denomination and musical style and/or preferences of the congregation). The construct also refers to the tempo, volume and instruments played. In the next section, signs and symbols, as well as layout and design, are discussed as examples of how physical cues can influence the servicescape of a church service.

\section{Signs and symbols as physical atmospheric cues}

Signs and symbols communicate explicit or subliminal messages (regarding the servicescape) to consumers (Bitner 1992:66), and consumers are inclined to make subjective evaluations about the service, based on how they perceive the servicescape (Countryman \& Jang 2006:536). Signs in particular communicate explicit messages since they usually act as labels, communicate rules of behaviour or provide direction. Other objects in the servicescape, such as symbols, may send implicit messages regarding quality, status, norms and expectations (Bitner 1992:66).
Symbols in churches that relate to the Christian religion and specific denominations could include pictures inside the church, the specific theme that is visually displayed in the church or various representations of the cross. Young adults are able to make assumptions concerning the overall atmosphere of the church based on the signage and religious symbols in the servicescape. For example, the religious symbol of an empty cross conveys the symbolic message and metaphor that Jesus died for the sins of mankind and then rose from the grave, leaving the cross empty. The empty cross is a sign of Jesus conquering death and thus a symbol of hope. The message forms part of the religious teachings and foundations of all three denominations selected for the purpose of this research, namely the Dutch Reformed Church, the Reformed Church and Doxa Deo. In addition to the effect of music, this research explored whether the signs and symbols in the church are perceived to: (1) create a specific atmosphere (Morin et al. 2007:118) that stirs religious feelings; (2) provide a visual, non-verbal, symbolic message closely associated with religion; (3) direct and inform (Bitner 1992:66) church members; and (4) create a religious church experience (Countryman \& Jang 2006:536).

\section{Layout and design as physical atmospheric cues}

The layout of the servicescape refers to the manner in which furniture is arranged, the size and shape of furniture and the spatial relationships (distances) between the items, whereas functionality refers to the ability of the items in the servicescape to facilitate performance (Bitner 1992:66). Hence, the purpose of the servicescape layout and design is to create a functional, practical, attractive and efficient service environment. An appropriate servicescape design can encourage the efficient use of the space and create a specific atmosphere (Greenland \& McGoldrick 1994:4). The church design can create a servicescape that stirs religious feelings since the intended atmosphere is communicated by the design and layout of the servicescape.

Services that are rendered in a church are of an interpersonal nature, therefore the design and layout must be structured in such a way that contact between the consumer and the service provider (the congregation and the church) is possible (Bitner 1992:63). The layout and design of any servicescape should take crowding into account, since crowding affects the functionality of a servicescape. Crowding refers to the perceived and/or actual density of the environment in which consumers find themselves (Harrell, Hutt \& Anderson 1980:45). A consumer's perception of the servicescape, satisfaction and behaviour is usually negatively influenced by crowding (Harrell et al. 1980:46). Young adults might decide not to return to the church or leave a church service early because of crowding. The servicescape layout should thus minimise crowding (Countryman \& Jang 2006:537) to create a favourable atmosphere. This research explored whether the layout and design were perceived to (1) create a specific atmosphere (Morin et al. 2007:118) that stirs religious feelings; (2) create an attractive physical service environment 
(Morin et al. 2007:118) that is stimulating to young adults; (3) consider aspects of crowding (Harrell et al. 1980:47); (4) allow optimal use of space (Greenland \& McGoldrick 1994:4) in the church; (5) facilitate interaction between the young adults and the pastor or preacher (Bitner 1992:63); and (6) support practical and/or functional aspects of the service (Harrell et al. 1980:47).

\section{Research method and design}

The research followed a quantitative research design, making use of structured questionnaires which were completed by young adults between the ages of 18 and 30 after services either in a Dutch Reformed, a Reformed or a Doxa Deo church.

\section{Sampling}

A non-probability sampling technique, namely convenience sampling (Cooper \& Schindler 2006:424), was used to collect the data. The three churches that participated in the research were selected based on their willingness to participate in the research through informed consent, geographical proximity to the researcher and the need for face-to-face contact during the data collection phase. All the churches that participated in the research were based in Pretoria and Johannesburg, and young adults were requested to participate voluntarily in the survey.

In view of the sensitive and personal nature of religion, church attendance and differences in church denominations, anonymous self-completion questionnaires were used to allow respondents to respond freely and minimise potential bias that could be caused by socially desirable responses. Respondents signed the questionnaire to indicate that they had willingly and voluntarily participated in the research.

\section{Measurement instrument}

The items that were used to measure the constructs were developed in phases. Items from existing literature were used and adapted to suit the uniqueness of the church service as a service. New items were developed, and the questionnaire was pretested to ensure that items were not confusing or ambiguous.

The questionnaire (see Appendix A) consisted of four sections. Section A required background information and included frequency of church attendance, gender and age variables. Sections B, C and D pertained to the atmospheric cues, namely music, signs and symbols as well as layout and design.

Four aspects were measured within each atmospheric cue sub-section (sections B, C and D). Firstly, the experience of the service that was attended just before the interview was measured, using a five-point Likert scale (Cooper \& Schindler 2006:337) ranging from 1 ('Strongly disagree') to 5 ('Strongly agree') to measure the agreement with each statement. Secondly, likability (as an overall aggregate measure for each atmospheric cue) was used to measure the extent to which young adults liked the music, the signs and symbols and the layout and design in the church, using a 10-point scaled response question, with a score of 1 indicating a strong dislike $\left(1={ }^{\prime}\right.$ Did not like at all' $)$ and 10 indicating a strong liking $(10=$ 'Liked it very much'). Third, a yes/no dichotomous question (Cooper \& Schindler 2006) was used to enquire whether the atmospheric cue played a role in the motivation to attend a service and whether a change in the atmospheric cue would increase attendance. Lastly, the attributes of an ideal service as perceived by the attendees of the service was measured. The attributes were measured on a sevenpoint semantic differential scale with polar adjectives of the creative elements on each scale end. In addition, in section B, respondents were asked which one of four statements best described the praise and worship style during the service.

\section{Results}

Principle component analysis is a widely used statistical method which is very useful in reducing the dimensions of several sets of variables. Principal component analysis is a method whereby the total variance of the sets of variables in the analysis is accounted for. The number of principal components to extract is an arbitrary decision, and one of the most useful guidelines is the mineigen criterion, which stipulates that the number of factors to extract should ideally correspond to the number of eigenvalues greater than 1 (see Table 1). The initial factor loadings extracted often do not offer a clearly interpretable solution; therefore, a rotation of the axes is recommended. The varimax method of rotation produces uncorrelated factor patterns, which are often useful for the purpose of the analysis as dimension reduction (Hair et al. 1998).

This research explored the physical and non-physical cues describing the church servicescape, as perceived by the congregation. Items were developed to measure music experience, signs and symbols as well as layout and design as elements of the church servicescape. The items were subjected to principal component analysis (PCA) in order to determine the dimensionality of the servicescape and to find a smaller number of useful dimensions to report on.

The number of factors to be extracted was determined by the mineigen criterion, and since eight eigenvalues were greater than 1, eight factors were extracted. The eigenvalues as well as the percentage of variance explained are reported in Table 1.

The varimax rotated factor loadings and corresponding factors that were identified are displayed in Table 2. The last two factors that were extracted did not produce a clear meaning and are therefore not reported. The six clearly interpretable factors were music experience, layout and design, functionality, appropriateness, atmospherics and signs and symbols.

The six factors were combined into composite scores by averaging the items corresponding to each factor. Negatively 
phrased items, marked by a dagger in Table 2, were reverse coded before the composite scores or reliability statistics were calculated.

The first factor, music experience, captures the general enjoyment and likability of the tempo and volume of music. The second factor reflects a general evaluation of the layout and design and positioning of the chairs and podium in the church. The third factor, functionality, is a measure of practical issues and functional design of the church. Appropriateness, the fourth factor, has to do with whether both the music and design of the church is appropriate for expression of religion. The fifth factor, atmospherics, is concerned with whether the layout and design of the church are conducive to the creation of the appropriate atmosphere to facilitate the religious rituals. Factor six, signs and symbols, pertains to how signs and symbols are experienced to be conducive to an expression of religion.

In order to evaluate the internal consistency reliability of the items measuring each factor, the Cronbach's coefficient alpha was calculated for the items loading towards each factor, with the results displayed in Table 3. The generally accepted cut-off criterion for alpha is 0.7 (Peterson 1994). It should be noted that only three of the six factors met this cut-off, and therefore the results of factors 4-6 should be interpreted with caution. A further consideration is that, for factors 2-6, only three items reflect the issue measured in the factor. With fewer items in a factor, it is appropriate to relax the cut-off criterion.

Table 4 displays the descriptive measures of the six factor scores for the entire group of respondents in this research. The means scores range between 1 and 5 (where 1 = 'Strongly disagree' to 5 = 'Strongly agree') and were calculated as an average of the respective items loading to a factor. The higher the mean value, the higher the general agreement that the factor contributed positively to the servicescape or the respondents' service experience.

From the interpretation of the means in Table 4, it is clear that respondents seemed to have a positive attitude regarding the different factors of their church experience. The most positive aspect of the service experience is that the young adults perceived the music to be appropriate and that they were satisfied with signs and symbols and layout and design in the church. The remaining factors also tended towards the positive side. However, on average, the sample of respondents did not experience any of the dimensions as being extremely positive since no mean value is above 4 , on a scale ranging from 1 to 5 . Therefore, there may be an opportunity to improve on all aspects of the servicescape.

Interesting insights could be gained from exploring differences in the mean levels of each factor as perceived by the respondents and by exploring differences between groups based on their frequency of church attendance and their loyalty in terms of being dedicated to a specific church and service. In addition, differences between gender
TABLE 1: The eigenvalues and percentage of variance explained in the principle component analysis.

\begin{tabular}{lll}
\hline Eigenvalues & $\begin{array}{l}\text { Percentage of variance } \\
\text { explained }\end{array}$ & $\begin{array}{l}\text { Cumulative percentage } \\
\text { of variance explained }\end{array}$ \\
\hline 4.410 & 18.4 & 18.4 \\
2.201 & 9.2 & 27.5 \\
2.035 & 8.5 & 36.0 \\
1.630 & 6.8 & 42.8 \\
1.314 & 5.5 & 48.3 \\
1.244 & 5.2 & 53.5 \\
1.095 & 4.6 & 58.0 \\
1.016 & 4.2 & 62.3 \\
\hline
\end{tabular}

TABLE 2: Principle component analysis with varimax rotation.

\begin{tabular}{|c|c|}
\hline Factors of the church servicescape & Loading \\
\hline \multicolumn{2}{|l|}{ Factor 1: Music experience } \\
\hline I like the tempo of the music in the church & 0.862 \\
\hline I like the volume of the music in the church & 0.822 \\
\hline $\begin{array}{l}\text { I enjoy the music being played in my church more than the music in } \\
\text { other churches }\end{array}$ & 0.664 \\
\hline $\begin{array}{l}\text { The music in the church does not reflect my own personal taste and } \\
\text { preference in music }\end{array}$ & -0.595 \\
\hline \multicolumn{2}{|l|}{ Factor 2: Layout and design } \\
\hline $\begin{array}{l}\text { The layout and design of the church facilitates interaction between me } \\
\text { and the pastor/preacher }\end{array}$ & 0.739 \\
\hline I like the current layout of the chairs/seats in the church & 0.681 \\
\hline I like the current position of the podium/stage in the church & 0.640 \\
\hline \multicolumn{2}{|l|}{ Factor 3: Functionality } \\
\hline $\begin{array}{l}\text { I feel that the layout and design of the church is more practical than in } \\
\text { other churches }\end{array}$ & 0.847 \\
\hline $\begin{array}{l}\text { I feel that the layout and design of the church is more functional than } \\
\text { in other churches }\end{array}$ & 0.789 \\
\hline $\begin{array}{l}\text { I think that the layout and design of the church is visually beautiful } \\
\text { and appealing }\end{array}$ & 0.447 \\
\hline
\end{tabular}

Factor 4: Appropriateness

I feel like the signs and symbols in the church are closely associated with my religion

The signs and symbols are appropriate for the type of church enomination

The music is appropriate for the type of church denomination Factor 5: Atmospherics

The layout and design of the church creates an atmosphere that stirs $\quad 0.822$ religious feelings

The layout and design of the church is appropriate for the type of

church denomination

The signs and symbols in the church create an atmosphere that elicits $\quad 0.459$ religious feelings

Factor 6: Signs and symbols

I can clearly see the signs and symbols in the church

$\dagger$ feel that the church does not use signs and symbols to display the $\quad-0.617$ theme of the church service

I like how signs and symbols are currently being used in the church

$\dagger$, Phrases were reverse coded before the composite scores or reliability statistics were calculated.

TABLE 3: Cronbach's coefficient alpha for the six interpretable factors.

\begin{tabular}{lll}
\hline $\begin{array}{l}\text { Factors of the church } \\
\text { servicescape }\end{array}$ & Number of items & Cronbach's alpha \\
\hline Factor 1: Music experience & 4 & 0.734 \\
Factor 2: Layout and design & 3 & 0.703 \\
Factor 3: Functionality & 3 & 0.716 \\
Factor 4: Appropriateness & 3 & 0.590 \\
Factor 5: Atmospherics & 3 & 0.535 \\
Factor 6: Signs and symbols & 3 & 0.537 \\
\hline
\end{tabular}

and age groups, based on their average experience of the servicescape, could also be informative.

Table $5 \mathrm{a}-5 \mathrm{~d}$ displays the results and the significance of the differences between subgroups based on the independent 
sample $t$-test. Table 5 a provides the mean factor scores of respondents who attended church on a weekly basis, compared to those who attended less frequently. The mean differences across all six dimensions of the servicescape are not significant, implying that frequency of attendance did not seem to have an influence on how the six-dimensional servicescape was experienced by church attendees. Table $5 b$ provides the results of comparing the group that reported that they consistently attended services at a specific church to those that attended different services. The means are also not significantly different across these two groups. Based on age (Table 5c), there are also no significant differences between those who were 21 and younger compared to those who were 22 and older. Lastly, except for the second factor, layout and design, and factor 6 , signs and symbols, there are no significant differences between males and females regarding how the servicescape of the church was experienced (Table $5 \mathrm{~d}$ ). At the $1 \%$ level of significance, females reported significantly higher levels of positive perceptions of the layout and design of the church, and at the 5\% level of significance, females were more positive than males about signs and symbols. These results could possibly be attributed to females' tendency to have a higher level of awareness of these aspects.

Another aspect that was explored was what respondents perceived to be an ideal church experience and the specific attributes of music, signs and symbols as well as layout and design they valued most. In order to obtain a measure of the attributes of each of these elements of the servicescape, a seven-point semantic differential scale was developed with bi-polar attributes on each point of a seven-point scale. The mean plots of the results are shown in Figures 1-3.

The results in Figure 1 suggest that, ideally, music should be tasteful and interesting (mean above 5) and should include singing (mean below 2) with a weak preference for no choirs (mean below 4). Insights are also gained from interpreting the aspects that are around the midpoint of the scale, namely close to 4 . The results suggest that there was a slightly stronger preference for modern music compared to organ music and for stimulating, loud and surprising music. However, the preference for loud music is somewhat contradictory in the sense that there seems to be a slight preference for calming music. The results also suggest that respondents did not seem to have a particularly strong preference for traditional versus non-traditional music, neither for using a lead singer versus no singer, nor for ordinary versus unusual music.

One should bear in mind that young adults have access to a large variety of music and that good quality music is abundantly available on mobile phones and other portable devices. Therefore, young adults have probably developed very discerning tastes regarding music quality. The results could possibly indicate that good quality, tasteful, suitable music that enhances the religious experience of church attendees and allows their full participation by allowing them to sing along possibly characterises the ideal situation that young adults prefer when attending church services.
TABLE 4: Descriptive statistics of the six factor scores describing the church servicescape.

\begin{tabular}{llll}
\hline $\begin{array}{l}\text { Factors of the church } \\
\text { servicescape }\end{array}$ & $N$ & Mean & SD \\
\hline Factor 1: Music experience & 200 & 3.71 & 0.79 \\
Factor 2: Layout and design & 200 & 3.70 & 0.84 \\
Factor 3: Functionality & 200 & 3.57 & 0.78 \\
Factor 4: Appropriateness & 200 & 3.95 & 0.72 \\
Factor 5: Atmospherics & 200 & 3.74 & 0.70 \\
Factor 6: Signs and symbols & 200 & 3.62 & 0.74 \\
\hline
\end{tabular}

$N$, number of respondents; SD, standard deviation.

TABLE 5a: Results of the $t$-test, exploring significant differences between frequency of attendance.

\begin{tabular}{lccc}
\hline Servicescape factors & \multicolumn{2}{c}{ Frequency of attendance } & Significance \\
\cline { 2 - 3 } & $\begin{array}{c}\text { Once a week } \\
(\boldsymbol{n}=\mathbf{1 1 2})\end{array}$ & $\begin{array}{c}\text { Less than once a } \\
\text { week }(\boldsymbol{n}=\mathbf{7 6})\end{array}$ & \\
\hline Factor 1: Music experience & 3.71 & 3.75 & 0.695 \\
Factor 2: Layout and design & 3.72 & 3.67 & 0.670 \\
Factor 3: Functionality & 3.59 & 3.54 & 0.688 \\
Factor 4: Appropriateness & 4.01 & 3.88 & 0.245 \\
Factor 5: Atmospherics & 3.76 & 3.78 & 0.912 \\
Factor 6: Signs and symbols & 3.63 & 3.61 & 0.846 \\
\hline
\end{tabular}

$n$, number of respondents.

TABLE 5b: Results of the $t$-test, exploring significant differences between loyalty to a church.

\begin{tabular}{lccc}
\hline Servicescape factors & \multicolumn{2}{c}{ Loyalty to a single church } & Significance \\
\cline { 2 - 3 } & $\begin{array}{c}\text { Only attend one } \\
\text { church } \\
(\boldsymbol{n}=\mathbf{1 1 2})\end{array}$ & $\begin{array}{c}\text { Attend more than } \\
\text { one church } \\
(\boldsymbol{n}=\mathbf{8 8})\end{array}$ & \\
\hline Factor 1: Music experience & 3.73 & 3.67 & 0.617 \\
Factor 2: Layout and design & 3.68 & 3.73 & 0.661 \\
Factor 3: Functionality & 3.51 & 3.64 & 0.244 \\
Factor 4: Appropriateness & 4.02 & 3.86 & 0.132 \\
Factor 5: Atmospherics & 3.75 & 3.73 & 0.828 \\
Factor 6: Signs and symbols & 3.71 & 3.50 & 0.048 \\
\hline
\end{tabular}

$n$, number of respondents.

TABLE 5c: Results of the $t$-test, exploring significant differences between age groups.

\begin{tabular}{lccc}
\hline Servicescape factors & \multicolumn{2}{c}{ Age } & Significance \\
\cline { 2 - 3 } & $\begin{array}{c}\mathbf{2 1} \text { and younger } \\
(\boldsymbol{n}=\mathbf{9 3})\end{array}$ & $\begin{array}{c}\mathbf{2 2 +} \\
(\boldsymbol{n}=\mathbf{1 0 7})\end{array}$ & \\
\hline Factor 1: Music experience & 3.67 & 3.73 & 0.584 \\
Factor 2: Layout and design & 3.75 & 3.66 & 0.492 \\
Factor 3: Functionality & 3.59 & 3.55 & 0.738 \\
Factor 4: Appropriateness & 3.99 & 3.92 & 0.472 \\
Factor 5: Atmospherics & 3.72 & 3.76 & 0.669 \\
Factor 6: Signs and symbols & 3.63 & 3.61 & 0.851 \\
\hline
\end{tabular}

$n$, number of respondents.

TABLE 5d: Results of the $t$-test, exploring significant differences between genders.

\begin{tabular}{lccc}
\hline Servicescape factors & \multicolumn{2}{c}{ Gender } & Significance \\
\cline { 2 - 3 } & $\begin{array}{c}\text { Male } \\
(\boldsymbol{n}=\mathbf{9 4})\end{array}$ & $\begin{array}{c}\text { Female } \\
(\boldsymbol{n}=\mathbf{1 0 6})\end{array}$ & \\
\hline Factor 1: Music experience & 3.68 & 3.73 & 0.653 \\
Factor 2: Layout and design & 3.50 & 3.88 & $0.001 \uparrow$ \\
Factor 3: Functionality & 3.52 & 3.61 & 0.423 \\
Factor 4: Appropriateness & 3.91 & 3.98 & 0.474 \\
Factor 5: Atmospherics & 3.68 & 3.80 & 0.266 \\
Factor 6: Signs and symbols & 3.49 & 3.73 & $0.026 \$$ \\
\hline
\end{tabular}

$n$, number of respondents.

$\dagger$, Significant at the $1 \%$ level of significance.

$\checkmark$ Significant at the $5 \%$ level of significance.

The results in Figure 2 suggest that the respondents felt that the ideal servicescape should make use of a good combination of colours (mean above 5) and that the signs and symbols should be inspiring (mean above 5) and sophisticated (mean just below 5). The attributes with a mean close to 3 indicate 
that the respondents felt that signs and symbols should preferably be calm (not busy), bright, with a wide range of colours and exciting. The mean scores below 3 indicate that they felt the use of colour should be modern, artistic and creative and therefore warrants careful use in order not to be too busy or unsophisticated.

The results provided in Figure 3 suggest that attributes of layout and design should ideally be inviting and comfortable (mean value above 5), artistic (mean value below 5) and uncluttered, provide sufficient space and be functional, cosy and welcoming (mean value below 3). There appears to be a moderate preference for a traditional, yet modern approach, with appropriate technology (mean value above 4). Once again, the results suggest that the layout and design should be approached with caution since the young adults considered layout and design to be an important element in the servicescape.

There seemed to be a very strong preference for an inviting, welcoming, comfortable and cosy space. However, these four attributes that were categorised under layout and design are not strictly speaking aspects related to the physical layout and design but rather non-tangible atmospherics. These attributes are possibly more part of the sense of community that is created, which has much more to do with aspects that are most closely aligned with the Christian philosophy of acceptance, friendliness, patience and love. This finding may suggest that these are the essential elements of how the servicescape of the church can be described.

The general likability of each of the design aspects was also gauged by asking respondents on a scale ranging from 1 to 10 (where $1=$ 'Did not like at all' and $10=$ 'Liked very much') how much they liked the music, signs and symbols and the layout and design in the church. The mean scores on these three questions, presented in Table 6, suggest that respondents perceived music to be the most likable aspect of the service that they attended, then layout and design and lastly signs and symbols. However, both the visual aspects of signs and symbols and layout and design were less liked than music. There seems to be some room for improving on these aspects since none of the scores were close to 10 .

Table 7 describes the influence of the servicescape elements on current and future church attendance. The results indicate that the music in the church is a very strong motivator to attend church services and that church attendance could possibly be most effectively enhanced by addressing the type and quality of music in order to appeal to the preferences of young adults.

\section{Discussion}

Not surprisingly, the sample of respondents reported a positive experience of the service they attended. Of the sample, $60 \%$ indicated that they attended a church service

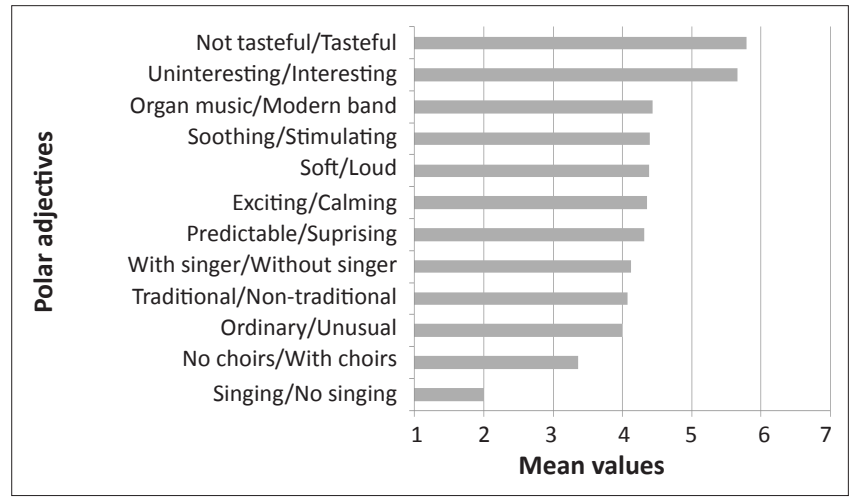

FIGURE 1: Mean attributes of music in the ideal church servicescape.

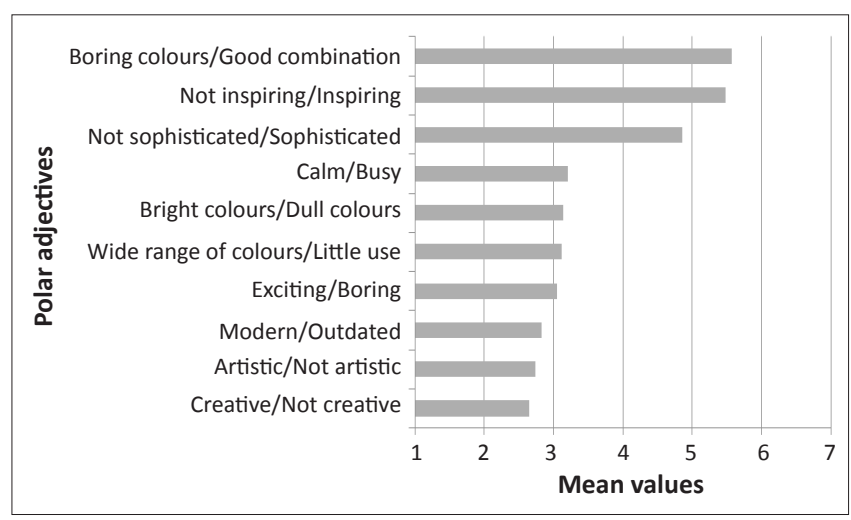

FIGURE 2: Mean attributes of signs and symbols in the ideal church servicescape.

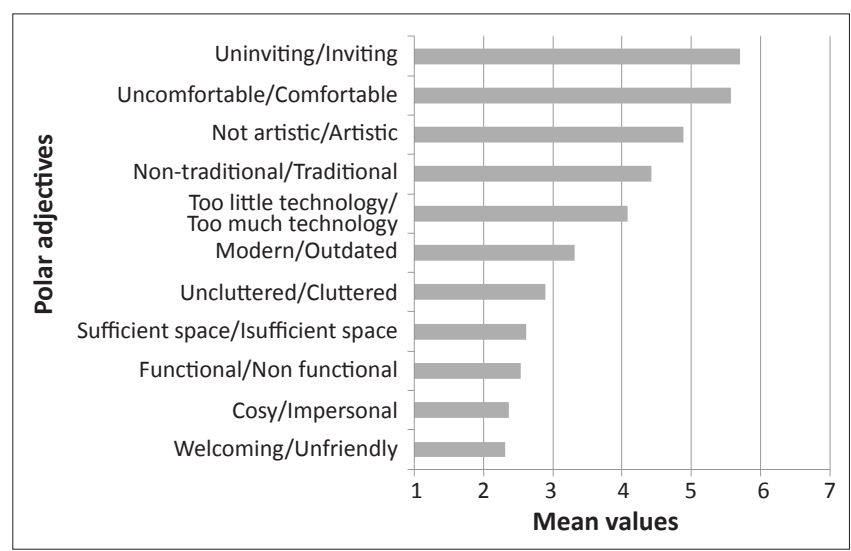

FIGURE 3: Mean attributes of layout and design in the ideal church service.

once a week, and an additional 25\% (that is, $85 \%$ in total) attended a service at least three times a month. Only $6 \%$ of respondents attended church less than once a month.

Regular attendees in the church form the church community, and they are the essence of the congregation. Despite the fact that the sample consisted mainly of people who regularly attend services, $44 \%$ indicated that they attend services at more than one church, which indicates polygamous loyalty, a term coined by Dowling and Uncles (1997:74), implying in the context of this research that those respondents' loyalty is not devoted to a single church. Dowling and Uncles (1997:74) observed that divided loyalty is quite common in various products and industries. The reasons for not remaining loyal may not be disloyalty but rather that consumers either need 
TABLE 6: The mean likability of elements of the servicescape as perceived by respondents.

\begin{tabular}{llll}
\hline Elements of the servicescape & $\boldsymbol{N}$ & Mean & SD \\
\hline Music likability & 200 & 7.47 & 1.730 \\
Likability of signs and symbols & 200 & 6.97 & 1.932 \\
Likability of layout and design & 200 & 7.07 & 1.779 \\
\hline
\end{tabular}

$N$, number of respondents; SD, standard deviation.

TABLE 7: Whether the servicescape motivates current and future church attendance.

\begin{tabular}{lc}
\hline Church attendance & Yes (\%) \\
\hline $\begin{array}{l}\text { Current } \\
\begin{array}{l}\text { Does the music being played in your church motivate you to attend } \\
\text { church services? }\end{array}\end{array}$ & 67.5 \\
$\begin{array}{l}\text { Do the current signs and symbols used in your church motivate you to } \\
\text { attend church services? }\end{array}$ & 48.0 \\
$\begin{array}{l}\text { Does the layout and design of your church motivate you to attend church } \\
\text { services? }\end{array}$ & 36.5 \\
$\begin{array}{l}\text { Future } \\
\begin{array}{l}\text { Do you think that your church attendance would increase if the current } \\
\text { music in your church changed? }\end{array}\end{array}$ & 35.5 \\
$\begin{array}{l}\text { Do you think that your church attendance would increase if the current } \\
\text { signs and symbols in your church changed? }\end{array}$ & 25.0 \\
$\begin{array}{l}\text { Do you think that your church attendance would increase if the current } \\
\text { layout and design in your church changed? }\end{array}$ & 23.0 \\
\hline
\end{tabular}

variety or the other product or service could have been more convenient at a certain point in time.

A key finding was that atmospherics, relating to a welcoming, homely, cosy and friendly atmosphere, are more important than the physical aspects of layout and design. Similarly, modern and colourful signs and symbols that are traditional, yet modern and artistic seem to be preferred. Lastly, music seems to be the most important aspect that has an effect on the experience of church attendees.

In research on psychological mechanisms of music on store evaluation in a retail context, Dubé and Morin (2001:111-112) found that 'background music exert $[s]$ influence on store evaluation but the effect does not occur through automatic transfer of affect'. The intensity of the pleasure brought by music had a positive effect towards perceptions of the servicescape. Dubé and Morin also found an indirect mechanism which also had an effect of a more positive attitude towards sales staff, which in turn resulted in a more positive evaluation of the store. They (Dubé \&Morin 2001:111-112) implied in their findings that the demand on sales staff may be alleviated when atmospherics and other design characteristics enhance the service experience, which may suggest that an enhanced musical experience may alleviate the expectations from other 'service staff', for example the preacher.

Music is a very important aspect in the life of young people as it assists in identity formation and is a popular pastime (Saxton 2005:26). However, as Lin (2004:164) has indicated, from a Gestalt theory perspective, a consumer's experience of a servicescape is a holistic experience. According to Schiffman (2001:213), perceptions cannot be deconstructed into their elementary components or sensation. Perceptions are therefore the 'Gestalts' or perceptions of the environment as a totality and not as its individual elements. Therefore, the perceptions of church attendees include not just what they see, but also what they hear and who they see. According to Lin (2004:164), individuals in a service context form a holistic concept of the servicescape. There is cognitive activity that precedes emotional activity, which in turn is followed by cognitive appraisal to which individuals respond in either approach or avoidance behaviour. Therefore, the results suggest that a positive servicescape could improve church attendance, but the authors would like to argue that investments in the servicescape alone are not sufficient.

Although this research suggested that there seems to be more than the servicescape that attracts young adults to attend church, this finding does not mean that none of the perspectives from a traditional commercial marketing context could be worth exploring for feasibility in a non-profit organisation such as the church. Other perspectives within marketing literature are mentioned that may offer interesting insights. For example, Zomerdijk and Voss (2010:77) suggested the use of 'customer journeys' and 'touchpoints' to enhance sensory experience design. Tombs and McCollKennedy (2003:465) mention that, in addition to atmospheric cues, the social aspects of the environment should not be neglected and presented a social-servicescape model whilst Wägar et al. (2012:153) suggested a framework for examining blind spots, which obstruct the service provider's ability to correctly interpret current customer relationships and the stability of such relationships, which may influence loyalty. Such perspectives might be worth exploring.

\section{Limitations and recommendations for future research}

Only young adults who were church attendees were interviewed. It is therefore suggested that, in future research, non-attendees should be interviewed. It should also be pointed out that young adults from only three church denominations in Johannesburg and Pretoria were interviewed.

Future research that attempts to explain what may motivate people to attend church needs to delve much deeper than the servicescape from a commercial marketing perspective to perhaps include religion as the marketing of an idea. Deeper theological reflection on the usability of a marketing approach in the life and ministry of the church - especially taking the identity of the church into account - is needed since the scope of the article did not allow for this issue to be addressed.

\section{Conclusion}

The question remains whether changes to the church servicescape will influence church attendance. This research investigated how young adults perceived different aspects of the servicescape, and the results were compared across those who attended frequently and those who attended less frequently as well as across those who only attended one church, versus those who attended more than one church. Possible differences in age groups and gender groups were also explored. 
The results showed that, although music was the most prominent atmospheric cue considered by young adults to influence church attendance, it was not a significant determinant between those who attended church once a week and those who attended church less frequently. There was, however, a significant difference in the perceptions of males and females regarding the visual aspects of layout and design, and signs and symbols. This finding may also be attributed to females' general heightened awareness of these aspects due to traditional female roles in society.

The perceived experience of the church servicescape was not significantly different between those who attended weekly and those who attended less frequently. It also did not differ for those who displayed polygamous loyalty or between younger and older respondents. This finding may suggest something else, for example, the actual message and sense of communion and fellowship may possibly be more likely to determine whether or not young adults attend church.

To conclude, although churches in the Western world are currently facing a crisis of lower attendance and less involvement, this research shows that superficial changes to the church servicescape may be very limiting in increasing church attendance. Church attendance is possibly the outcome of a much deeper involvement to attract people to each other and to God. Therefore, over and above the message that is proclaimed and the people involved in proclaiming the message, there may be much deeper individual needs: a need to find meaning, to connect or to find oneself among others; a need to contribute, to be fully emerged, to be part of a greater community and to serve God by serving others in constructive engagement.

\section{Acknowledgements Competing interests}

The authors declare that they have no financial or personal relationship(s) that may have inappropriately influenced them in writing this article.

\section{Authors' contributions}

M.C.v.d.M. (University of Pretoria) acted as supervisor for L.O.'s (University of Pretoria) Master's coursework research project. A.F.G. (University of Pretoria) and A.S. (University of Pretoria) in their capacity as co-supervisors made conceptual contributions toward the research and assisted with the questionnaire design. M.C.v.d.M., A.F.G. and A.S. reworked the literature review, results, discussion and conclusions. A.S. assisted with the data analysis and interpretation of the results.

\section{References}

Bitner, M.J., 1992, 'Servicescapes: The impact of physical surroundings on customers and employees', Journal of Marketing 56(2), 57-71. http://dx.doi. org/10.2307/1252042

Britz, J.J. \& Müller, J.C., 2003, 'A marketing and marketable church', Practical Theology in SA18(2), 1-12, viewed 26 January 2012, from http://0-search.sabinet.co.za. innopac.up.ac.za/WebZ/Authorize?sessionid=0\&bad=ejour/ejour_badsearch.h $\mathrm{ml}$ \&portal=ejournal\&next=images/ejour/practheo/practheo_v18_ñ_a1.pdf.।
Bruner II, G.C., 1990, 'Music, mood and marketing', Journal of Marketing 54(4), 94-104. http://dx.doi.org/10.2307/1251762

Cooper, D.R. \& Schindler, P.S., 2006, Business research methods, 9th edn., McGrawHill, New York.

Countryman, C.C. \& Jang, S-C., 2006, 'The effects of atmospheric elements on consumer impression: The case of hotel lobbies', International Journa of Contemporary Hospitality Management 18(7), 534-545. http://dx.doi. org/10.1108/09596110610702968

Dowling, G.R. \& Uncles, M., 1997, 'Do customer loyalty programmes really work?', Sloan Management Review 38(4), 71-82, viewed 10 July 2012, from http://0 content.ebscohost.com.innopac.up.ac.za/pdf19_22/pdf/1997/SMR/01Jun97/9712 235899pdf? $T=P \& P=A N \& K=9712235899 \& S=R \& D=b u h \& E b s c o C o n t$ o50SeqK44yOvqOLCmrOqeprVSr6e4SbaWxWXS\&ContentCustomer=dGJyMPGnr Oq2rLBLuePfgeyx44Dt6fIA

Dreyer, Y., 2004, 'A public practical theological theory for religious education of secularised youth', HTS Teologiese Studies/Theological Studies 60(3), 919-945. http://dx.doi.org/10.4102/10.4102/hts.v60i3.615

Dubé, L. \& Morin, S., 2001, 'Background music pleasure and store evaluation: Intensity effects and psychological mechanisms', Journal of Business Research 54(2), 107113. http://dx.doi.org/10.1016/S0148-2963(99)00092-2

Eroglu, S.A., Machleit, K.A. \& Davis, L.M., 2001, 'Atmospheric qualities of online retailing: A conceptual model and implications', Journal of Business Research 54(2), 177-184 http://dx.doi.org/10.1016/S0148-2963(99)00087-9

Greenland, S.J. \& McGoldrick, P.J., 1994, 'Atmospherics, attitudes and behaviour: Modelling the impact of designed space', The International Review of Retail, Distribution and Consumer Research, 4(1) 1-16. http://dx.doi. org/10.1080/09593969400000001

Hair, J.F. Jr., Anderson, R.E., Tatham, R.L. \& Black, W.C., 1998, Multivariate data analysis, 5th edn., Prentice-Hall International, Upper Saddle River.

Harrell, G.D., Hutt, M.D. \& Anderson, J.C., 1980, 'Path analysis of buyer behaviour under conditions of crowding', Journal of Marketing Research 17(1), 45-51. http://dx.doi.org/10.2307/3151115

Herrington, J.D., 1996, 'Effects of music in service environments: A field research', Journal of Services Marketing 10(2), 26-41. http://dx.doi. org/10.1108/08876049610114249

Howitt, Q.J., 1998, Worship and prayer, SATS, Johannesburg.

Lamb, C.W., Hair, J.F., McDaniel, C., Boshoff, C., Terblanche, N.S., Elliott, R. \& Klopper, H.B., 2010, Marketing, 4th edn., Oxford University Press, Cape Town.

Lin, I.Y., 2004, 'Evaluating a servicescape: The effect of cognition and emotion', International Journal of Hospitality Management 23(2), 163-178. http://dx.doi. org/10.1016/j.ijhm.2003.01.001

Man, R., 1998, 'Worship for all of God's people: Bridging the generation gap', in Worship Resources International, viewed 10 July 2012, from http://www.worr. org/by_ron_man.php

Morin, S., Dubé, L. \& Chebat, J., 2007, 'The role of pleasant music in servicescapes: A test of the dual model of environmental perception', Journal of Retailing 83(1), 115-130. http://dx.doi.org/10.1016/j.jretai.2006.10.006

North, E.J., 2004, 'The role of marketing in the church', Journal for Christian Scholarship 40(1/2), 99-115, viewed 26 January 2012, from http://0-search. sabinet.co.za.innopac.up.ac.za/WebZ/images/ejour/tcwet/tcwet_v40_n1_ a6.pdf?sessionid $=01-65180-187112162 \&$ format $=F$

Peterson, R.A., 1994, 'A meta-analysis of Cronbach's coefficient alpha', Journal of Consumer Research 21(2), 381-391. http://dx.doi.org/10.1086/209405

Proctor, T. \& Kitchen, P., 2002, 'Communication in postmodern integrated marketing', Corporate Communications: An International Journal 7(3), 144-154, viewed 01 February 2012, from http://0-www.emeraldinsight.com.innopac.up.ac.za/ journals.htm?articleid=858046\&show=abstract

Rosenbaum, M.S. \& Massiah, C., 2011, 'An expanded servicescape perspective', Journal of Service Management 22(4), 471-490. http://dx.doi. org/10.1108/09564231111155088

Santos, J. \& Mathews, P., 2001, 'Quality of religious services', International Journal of Non-profit and Voluntary Sector Marketing 6(3), 278-288. http://dx.doi. org/10.1002/nvsm.153

Saxton, G., 2005, "'Collections of cool", Young consumers: Insight and ideas for responsible marketers', Young consumers 6(2), 18-27. http://dx.doi. org/10.1108/17473610510680786

Schiffman, H.R., 2001, Sensation and perception, 5th edn., Wiley, New York.

Sherman, A. \& Devlin, J., 2000, 'American and British clergy attitudes towards marketing activities: A comparative research', The Service Industries Journal 20(4), 47-61. http://dx.doi.org/10.1080/02642060000000046

Tombs, A. \& McColl-Kennedy, J.R., 2003, 'Social-servicescape conceptual model', Marketing Theory 3(4), 447-475. http://dx.doi.org/10.1177/1470593103040785

Wägar, K., Roos, I., Ravald, A. \& Edvardsson, B., 2012, 'My customers are in my blind spot: Are they changing and I cannot see it?', Journal of Service Research 15(2), 150-165. http://dx.doi.org/10.1177/1094670511435540

Wilson, S., 2003, 'The effect of music on perceived atmosphere and purchase intentions in a restaurant', Psychology of Music 31(1), 93-112. http://dx.doi. org/10.1177/0305735603031001327

Zeithaml, V.A., Bitner, M.J. \& Gremler, D.D., 2006, Services marketing: Integrating customer focus across the firm, 4th edn., McGraw-Hill, New York.

Zomerdijk, L.G. \& Voss, C.A., 2010, 'Service design for experience-centric services', Journal of Service Research 13(1), 67-82. http://dx.doi. org/10.1177/1094670509351960

Appendix A starts on next page $\rightarrow$ 


\section{Appendix A}

Please answer ALL the questions. There are no right or wrong answers. Mark answers with a cross (X).

\section{How often do you attend church?}

\begin{tabular}{|l|r}
\hline Weekly & 1 \\
\hline Three times per month & 2 \\
\hline Twice a month & 3 \\
\hline Once a month & 4 \\
\hline Less than once a month & 5 \\
\hline
\end{tabular}

2. If you attend services at more than one church, please name the other church(es) and provide an estimate of the percentage of services in a typical year you prefer to attend at the different churches. (Must add up to 100.)

Please name the three churches that you attend most often.

Please name church that you attend most often:

Please name church that you attend second most:

Please name church that you attend third most:

All other:

Percentage of weeks that you do not attend any church service

TOTAL MUST ADD TO $100 \%$

3. Please indicate your gender.

Male

Female

4. Please indicate your age group.

Younger than 18

$18-21$

$22-25$

$26-35$

$36+$

Percentage of time in typical year

\section{- SECTION B: MUSIC -}

This section refers to the music being played in the church, taking into account the church denomination and musical style or preferences of the congregation. It also refers to the tempo, volume and instruments.

5. Please tick the appropriate box and indicate which best describes the praise and worship or musical style in your church's service.

Traditional (i.e. hymns and psalms)

Contemporary (i.e. lively music led by a band)

Mixture of traditional and contemporary style within a single church service

Multiple services with different styles (i.e. morning service with a more traditional approach; evening service with a more contemporary approach)

6. Please indicate your level of agreement/disagreement with the following statements, by marking your answer with a cross (X).

\begin{tabular}{|l|l}
\hline 6.1 & I feel that the music being played in the church creates an atmosphere that elicits religious feelings. \\
\hline 6.2 & Regard
\end{tabular}

\begin{tabular}{|l|l}
\hline 6.2 & Regardless of how much I liked or disliked the music in the church, it is appropriate for the type of church
\end{tabular} denomina

6.3 $\quad$ I enjoy listening to different instruments that are used to create the music in the church

\begin{tabular}{l|l}
6.4 & I like the tempo of the music in the church.
\end{tabular}

\begin{tabular}{l|l}
6.5 & I like the volume of the music in the church.
\end{tabular}

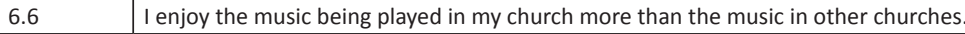

\begin{tabular}{l|l}
6.7 & The music in the church does not reflect my own personal taste and preference in music.
\end{tabular}

1
which you liked the music in your church.

Did not like at all

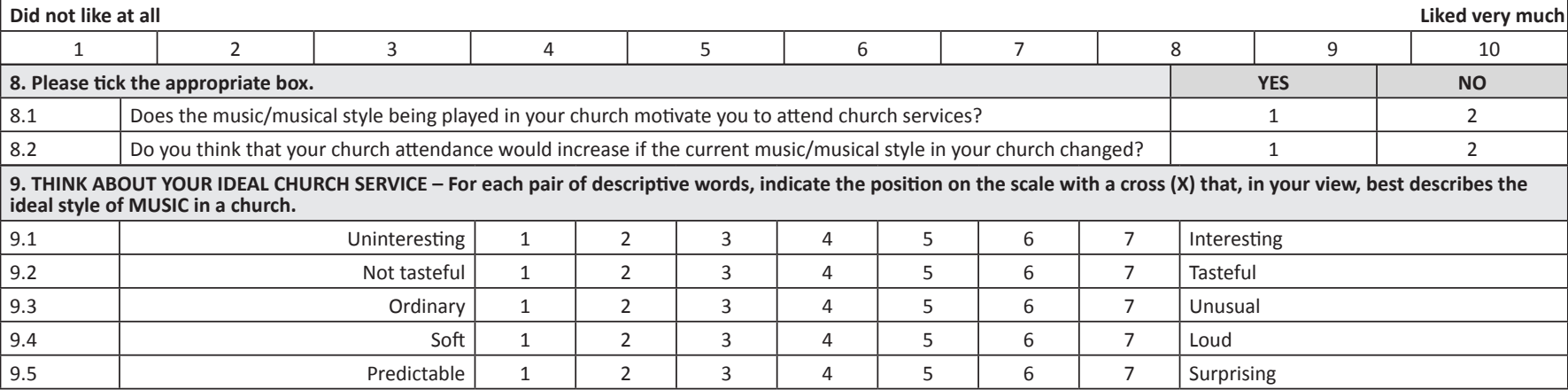




\begin{tabular}{|c|c|c|c|c|c|c|c|c|c|}
\hline 9.6 & Exciting & 1 & 2 & 3 & 4 & 5 & 6 & 7 & Calming \\
\hline 9.7 & Traditional & 1 & 2 & 3 & 4 & 5 & 6 & 7 & Non-traditional \\
\hline 9.8 & With lead singer & 1 & 2 & 3 & 4 & 5 & 6 & 7 & Without lead singer \\
\hline 9.9 & Organ music & 1 & 2 & 3 & 4 & 5 & 6 & 7 & Modern band \\
\hline 9.10 & Soothing & 1 & 2 & 3 & 4 & 5 & 6 & 7 & Stimulating \\
\hline 9.11 & No choirs & 1 & 2 & 3 & 4 & 5 & 6 & 7 & With choirs \\
\hline 9.12 & Singing & 1 & 2 & 3 & 4 & 5 & 6 & 7 & No singing \\
\hline
\end{tabular}

- SECTION C: SIGNS AND SYMBOLS -

10. Please indicate your level of agreement/disagreement with the following statements, by marking your answer with a cross (X).

10.1 I feel that the signs and symbols in the church create an atmosphere that elicits religious feelings. 10.2 Regardless of how much I liked or disliked the signs and symbols in the church, they are appropriate for the type of church denomination.

10.3 I feel that the church does not use signs and symbols to display the theme of the church service. 10.4 I can clearly see the signs and symbols in the church.

10.5 I like how signs and symbols are currently being used in the church.

10.6 I feel like the signs and symbols in the church are closely associated with my religion.

10.7 I feel that the signs and symbols in the church do not convey any symbolic meaning.

\begin{tabular}{|c|c|c|c|c|}
\hline $\begin{array}{c}\text { Strongly } \\
\text { Disagree }\end{array}$ & Disagree & Neutral & Agree & $\begin{array}{c}\text { Strongly } \\
\text { Agree }\end{array}$ \\
\hline 1 & 2 & 3 & 4 & 5 \\
\hline 1 & 2 & 3 & 4 & 5 \\
\hline 1 & 2 & 3 & 4 & 5 \\
\hline 1 & 2 & 3 & 4 & 5 \\
\hline 1 & 2 & 3 & 4 & 5 \\
\hline 1 & 2 & 3 & 4 & 5 \\
\hline
\end{tabular}

11. On a scale of 1 to 10 ( 1 indicating that you did not like the signs and symbols in your church at all and 10 being the highest possible rating you could give), please indicate the extent to which you liked the signs and symbols in your church.

Did not like at all

\begin{tabular}{|c|c|c|c|c|c|c|c|c|c|}
\hline 1 & 2 & 3 & 4 & 5 & 6 & 7 & 8 & 9 & 10 \\
\hline \multicolumn{8}{|c|}{ 12. Please tick the appropriate box. } & YES & NO \\
\hline 12.1 & \multicolumn{7}{|c|}{ Do the current signs and symbols in your church motivate you to attend church services? } & 1 & 2 \\
\hline 12.2 & \multicolumn{7}{|c|}{ Do you think that your church attendance would increase if the current signs and symbols in your church changed? } & 1 & 2 \\
\hline
\end{tabular}

13. THINK ABOUT YOUR IDEAL CHURCH SERVICE - For each pair of descriptive words, indicate the position on the scale with a cross (X) that, in your view, best describes the ideal style of SIGNS AND SYMBOLS in a church.

\begin{tabular}{|c|c|c|c|c|c|c|c|c|c|}
\hline 13.1 & Bright colours & 1 & 2 & 3 & 4 & 5 & 6 & 7 & Dull colours \\
\hline 13.2 & Calm & 1 & 2 & 3 & 4 & 5 & 6 & 7 & Busy \\
\hline 13.3 & Boring colours & 1 & 2 & 3 & 4 & 5 & 6 & 7 & Good combination of colours \\
\hline 13.4 & Not sophisticated & 1 & 2 & 3 & 4 & 5 & 6 & 7 & Sophisticated \\
\hline 13.5 & Exciting & 1 & 2 & 3 & 4 & 5 & 6 & 7 & Boring \\
\hline 13.6 & Not inspiring & 1 & 2 & 3 & 4 & 5 & 6 & 7 & Inspiring \\
\hline 13.7 & Creative & 1 & 2 & 3 & 4 & 5 & 6 & 7 & Not creative \\
\hline 13.9 & Artistic & 1 & 2 & 3 & 4 & 5 & 6 & 7 & Not artistic \\
\hline 13.10 & Wide range of colours & 1 & 2 & 3 & 4 & 5 & 6 & 7 & Little use of colour \\
\hline
\end{tabular}

\section{- SECTION D: LAYOUT AND DESIGN}

This section refers to the physical church building, more specifically to the structuring of the interior space. It indicates the way in which the space inside the church is utilised when looking at the chairs, lighting, podium, stage, etc.

\begin{tabular}{|c|c|c|c|c|c|c|}
\hline \multicolumn{2}{|c|}{$\begin{array}{l}\text { 14. Please indicate your level of agreement/disagreement with the following statements, by marking } \\
\text { your answer with a cross }(\mathrm{X}) \text {. }\end{array}$} & \multirow{2}{*}{$\begin{array}{c}\begin{array}{c}\text { Strongly } \\
\text { Disagree }\end{array} \\
1\end{array}$} & \multirow{2}{*}{$\begin{array}{c}\text { Disagree } \\
2\end{array}$} & \multirow{2}{*}{$\begin{array}{c}\text { Neutral } \\
3\end{array}$} & \multirow{2}{*}{$\begin{array}{c}\text { Agree } \\
4\end{array}$} & \multirow{2}{*}{$\begin{array}{c}\begin{array}{c}\text { Strongly } \\
\text { Agree }\end{array} \\
5\end{array}$} \\
\hline 14.1 & $\begin{array}{l}\text { I feel that the layout and design of the church creates an atmosphere that stirs religious } \\
\text { feelings. }\end{array}$ & & & & & \\
\hline 14.2 & $\begin{array}{l}\text { Regardless of how much I liked or disliked the layout and design of the church, it is } \\
\text { appropriate for the type of church denomination. }\end{array}$ & 1 & 2 & 3 & 4 & 5 \\
\hline 14.3 & I like the current layout of the chairs/seats in the church. & 1 & 2 & 3 & 4 & 5 \\
\hline 14.4 & I like the current position of the podium/stage in the church. & 1 & 2 & 3 & 4 & 5 \\
\hline 14.5 & I do not enjoy attending church services when there are lots of people in the church. & 1 & 2 & 3 & 4 & 5 \\
\hline 14.6 & I like going to church when there is enough room/space to move around in the church. & 1 & 2 & 3 & 4 & 5 \\
\hline 14.7 & $\begin{array}{l}\text { I feel that the current layout and design of the church facilitates interaction between me and } \\
\text { the pastor/preacher. }\end{array}$ & 1 & 2 & 3 & 4 & 5 \\
\hline 14.8 & I feel that the layout and design of the church is more functional than in other churches. & 1 & 2 & 3 & 4 & 5 \\
\hline 14.9 & I feel that the layout and design of the church is more practical than in other churches. & 1 & 2 & 3 & 4 & 5 \\
\hline 14.10 & I think that the layout and design of the church is visually beautiful and appealing. & 1 & 2 & 3 & 4 & 5 \\
\hline
\end{tabular}

15. On a scale of 1 to 10 (1 indicating that you did not like the layout and design of your church at all and 10 boing the highest possible rating you could give) please indicate the extent to which you liked the layout and design in your church.

Did not like at all

16. Please tick the appropriate box.

\begin{tabular}{|l|l|}
\hline 16.1 & Does the layout and design of your church motivate you to attend church services? \\
\hline 16.2 & Doyou think that your church attendance
\end{tabular}

\begin{tabular}{l|l}
16.2 & Do you think that your church attendance would increase if the current layout and design of your church changed?
\end{tabular}

Liked very much

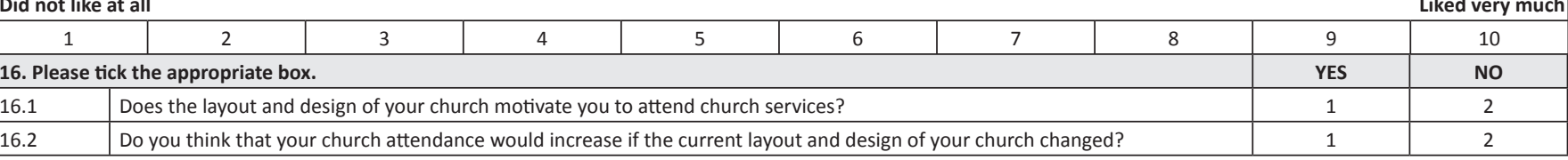




\begin{tabular}{|c|c|c|c|c|c|c|c|c|c|}
\hline \multicolumn{10}{|c|}{$\begin{array}{l}\text { 17. THINK ABOUT YOUR IDEAL CHURCH SERVICE - For each pair of descriptive words, indicate the position on the scale with a cross ( } \mathrm{X} \text { ) that, in your view, best describes the } \\
\text { ideal LAYOUT AND DESIGN in a church. }\end{array}$} \\
\hline 17.1 & Non-traditional & 1 & 2 & 3 & 4 & 5 & 6 & 7 & Traditional \\
\hline 17.2 & Modern & 1 & 2 & 3 & 4 & 5 & 6 & 7 & Out-dated \\
\hline 17.3 & Not artistic & 1 & 2 & 3 & 4 & 5 & 6 & 7 & Artistic \\
\hline 17.4 & Functional & 1 & 2 & 3 & 4 & 5 & 6 & 7 & Not functional \\
\hline 17.5 & Uncluttered & 1 & 2 & 3 & 4 & 5 & 6 & 7 & Cluttered \\
\hline 17.6 & Sufficient space & 1 & 2 & 3 & 4 & 5 & 6 & 7 & Insufficient space \\
\hline 17.7 & Too little technology & 1 & 2 & 3 & 4 & 5 & 6 & 7 & Too much technology \\
\hline 17.8 & Welcoming & 1 & 2 & 3 & 4 & 5 & 6 & 7 & Unfriendly \\
\hline 17.9 & Uncomfortable & 1 & 2 & 3 & 4 & 5 & 6 & 7 & Comfortable \\
\hline 17.10 & Uninviting & 1 & 2 & 3 & 4 & 5 & 6 & 7 & Inviting \\
\hline 17.11 & Cosy & 1 & 2 & 3 & 4 & 5 & 6 & 7 & Impersonal \\
\hline \multicolumn{10}{|c|}{ Thank you for your participation! } \\
\hline
\end{tabular}

